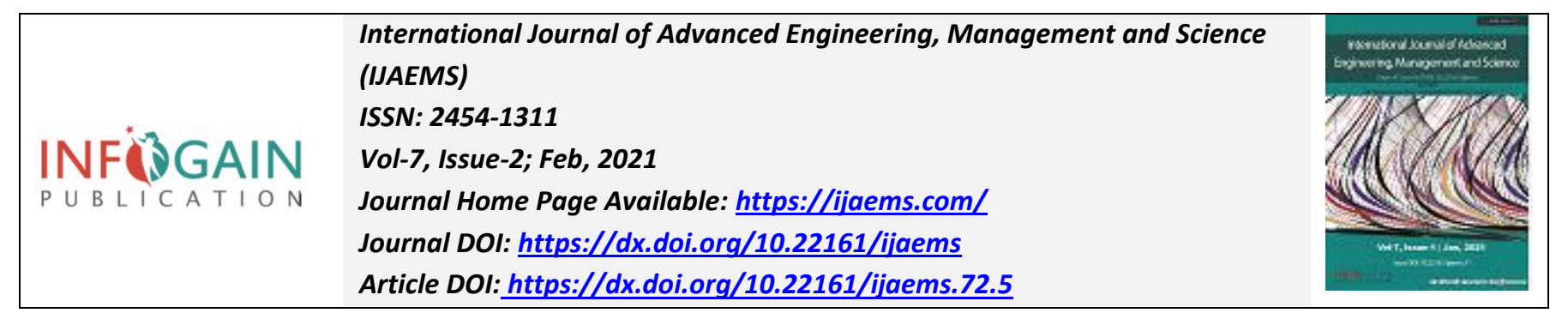

\title{
Correlates of Transformational and Transactional Leadership Styles of Entrepreneurs
}

\author{
Marilou P. Pascual, Mercedes D. Santos, Felipe E. Balaria, Cygrid M. Santos, Ara Deminice
}

\author{
I. Garcia, Nishe Klair R. Galang
}

Department of Graduate School - Business Administration Program, Nueva Ecija University of Science and Technology \& Cabanatuan City 3100, Philippines

Received: 30 Oct 2020; Received in revised form: 18 Jan 2021; Accepted: 03 Feb 2021; Available online: 14 Feb 2021

(C2021 The Author(s). Published by Infogain Publication. This is an open access article under the CC BY license

(https://creativecommons.org/licenses/by/4.0/).

\begin{abstract}
This study was conducted in the first semester of AY 2018-2019 in Cabanatuan City, Philippines which included describing the personal profile and leadership styles of the participants in the Kapatid Mentor Me Program of the Department of Trade and Industry. This Kapatid Mentor Me Program helps micro, small and medium entrepreneurs the business-know-how in sustaining and expanding their enterprise thru coaching and mentoring. The profile variables considered were sex, age, marital status, educational attainment and length of experience in entrepreneurship; while the management styles and motivation considered were the leadership theories categorized as transformational and transactional leaders. The questionnaire consisted of 24 statements related to the components of transformational leadership based on the study of Xiao, et al. in 2006 such as idealized influence, inspirational motivation, intellectual stimulation and individualized consideration and transactional leadership such as contingent reward, management-by-exception and laissezfaire leadership. It was based on a modified version of the Multi-factor Leadership Questionnaire (MLQ). The study revealed that the entrepreneurs involved in the program were mostly in their middle age, women, married, college graduate and has already earned a relatively long experience in their respective businesses. Pearson $r$ statistics shows that the profile variables did not significantly relate to any construct of either transactional and transformational leadership styles, except for age that negatively, but significantly correlated to transformational leadership. This means that the higher the age of the respondent, the lower his/her transformational leadership tendencies. This further implies that young entrepreneurs tend to be more transformational than their older counterparts.
\end{abstract}




\section{Keywords - transactional and transformational leadership, multi-factor leadership questionnaire, Kapatid Mentor Me Program Go Negosyo.}

\section{INTRODUCTION}

Leadership plays a very significant role in the success of businesses. It enables the entrepreneurs and managers to provide guidance and direction for employees. Businesses will get stagnant and can put the business in jeopardy without leadership. Every firm must therefore strive to have strong leadership to achieve its objectives and to maximize productivity because such leadership can motivate employees, initiate action, delegate responsibilities, build morale and improve the satisfaction that may later redound to success in any business endeavor.

There are two types of leadership hypothesized to have such an effect: transactional and transformational leadership. The concept of transformational leadership was initially introduced by leadership expert and presidential biographer, James MacGregor Burns, who explained that transactional leaders exchange tangible rewards for the work and loyalty of followers while transformational leaders engage with followers, focus on higher-order intrinsic needs, and raise consciousness about the significance of specific outcomes and new ways in which those outcomes might be achieved.

Bass (1998) extended the concept of transformational leadership to describe those who motivate followers to do more than they originally intended to do by presenting followers with a compelling vision and encouraging them to transcend their own interests for those of the group or unit. In fact, a defining characteristic of transformational leadership is the enormous personal impact it has on followers' values, aspirations, ways of thinking about work and interpreting events. Transformational leaders transform followers by transforming followers' values and beliefs.

Bass and Avolio (1998) later developed a "full range of leadership" model as illustrated in Figure 1. In the model, he presented three components that are characteristic of transactional leadership, namely: (1) Contingent Reward (CR); (2) Management-By-Exception (MBE); (3) LaissezFaire Leadership (LF), and five components which are characteristics of transactional leadership classified as 1) Idealized Influence (II), 2) Inspirational Motivation (IM), (3) Intellectual Stimulation (IS)(4) Individualized Consideration (IC) and Risk Acceptance (RA). The latter is characterized by an exchange relationship in which leaders motivate followers by providing them with rewards (or punishments) in return for follower effort (or lack of effort).

In this study, the transformational and transactional leadership styles of the entrepreneurs involved in Kapatid Mentor Me Program - Batch 1 and 2 of the Department of Trade and Industry - Cabanatuan City-were investigated.

The framework of the study lies on the assumption that transformational and transactional leadership influence the success of any business and that certain profile variables such as age, sex, civil status, highest educational attainment and length of service, on the other hand, influence one's leadership style.

The main objective of the study was to investigate the leadership styles of entrepreneurs involved in Kapatid Mentor Me Program - Batch 1 and 2 of the Department of Trade and Industry - Cabanatuan City. Specifically, it sought to 1) describe the entrepreneurs in terms of age, sex, civil status, highest educational attainment and length of service in entrepreneurship; 2) describe their transformational leadership tendencies in terms of Idealized Influence (II), Inspirational Motivation (IM), Intellectual Stimulation (IS), Individualized Consideration (IC), and Risk Acceptance (RA); 3) describe their transactional leadership tendencies in terms of Contingent Reward (CR), Management-ByException (MBE), and Laissez-Faire Leadership (LF); and 4) determine the relationship between the profile of entrepreneurs and their transformational as well as transactional leadership tendencies. 


\section{METHODOLOGY}

The study employed a descriptive method of research which, according to Dr. Y.P. Aggarwal (2008), is devoted to the gathering of information about prevailing conditions or situations for the purpose of description and interpretation. It aims to assess the leadership styles of entrepreneurs.

The respondents of this study were the entrepreneurs of Kapatid Mentor Me Program Batch 1 and 2 of the Department of Trade and Industry - Cabanatuan City. There were a total of forty (40) business entrepreneurs involved in the program; however, only thirty-three (33) of them were utilized as respondents in this study.

A survey questionnaire consisting of two parts was the primary tool used to gather data about the respondents' leadership styles. The first part of the questionnaire was used to gather information about the respondents' profile; while the second part, consisting of 24 items, was used to gather information about their leadership styles. The items which were based on a modified version of the Multi-factor Leadership Questionnaire (MLQ) developed by Bass and Avolio (1998), were adopted from a dissertation entitled Transformational Leadership VS. Transactional Leadership: The Influence of Gender and Culture on Leadership Styles of SMEs in China and Sweden by Pan Xiaoxia (2006).

A 7-point Likert scale is shown inTable 1 which the respondents chose the option on the extent of their views they agree or disagree on a particular question or statement.

Table 1. Point, Range, and Equivalent Verbal Analogy

\begin{tabular}{|c|c|c|}
\hline Point & Range & Verbal Analogy \\
\hline 7 & $6.22-7.00$ & Strongly Agree \\
\hline 6 & $5.35-6.21$ & Agree \\
\hline 5 & $4.48-5.34$ & Somewhat Agree \\
\hline 4 & $3.61-4.47$ & $\begin{array}{c}\text { Neither Agree nor } \\
\text { Disagree }\end{array}$ \\
\hline 3 & $2.74-3.60$ & Somewhat Disagree \\
\hline 2 & $1.87-2.73$ & Disagree \\
\hline 1 & $1.00-1.86$ & Strongly Disagree \\
\hline
\end{tabular}

\section{RESULTS AND DISCUSSION}

\section{Profile of Entrepreneurs}

The study revealed that the majority of the respondents were of age ranging from 40 to 49 , mostly female ( 20 or $60.6 \%$ ), married ( 28 or $84 \%$ ), college graduate (22 or $66.7 \%$ ), and into entrepreneurship for about 5 to nine years already (13 or $39.4 \%)$.

The figures further imply that married women take active participation in business entrepreneurship and that these women were not only educated but would also tend to be mature enough to handle the risks and pressures of business. Their relatively lengthy experience in the world of entrepreneurship would also tend to provide them with the opportunity to develop a style of leadership that would encourage successful dealingS with clients and employees, which may later redound to successful business endeavors.

\section{Transformational Leadership of Entrepreneurs}

In terms of transformational leadership, the study revealed that the respondents were highest in Inspirational Motivation (WM $=5.28)$ and Lowest in Risk Acceptance $(\mathrm{WM}=4.44)$

The finding is an indication that the respondents tend to encourage employees to make the most of their skills and capabilities, help them find meaning in their work and articulate with them a compelling vision for the future. They talk about what needs to be accomplished but express confidence that those goals will be achieved.

Bass, Bernard M., and Ruth Bass (2008) wrote that a person who uses inspirational motivation creates an exciting image of what is essential to consider. This type of motivational behavior encourages a sense of team spirit, creating general enthusiasm-especially towards difficult challenges, where enthusiasm and motivation are needed in order to maintain optimism throughout all levels of the organization. Considering all these, it is believed that the entrepreneurs involved in the Kapatid Mentor Me Program knew how to inspire their employees towards the success of their business endeavors. 
Table 2. Transformational Leadership Rating of Entrepreneurs

\begin{tabular}{|c|c|c|}
\hline Transformational & $\begin{array}{l}\text { Weighted } \\
\text { Mean }\end{array}$ & Verbal Description \\
\hline \multicolumn{3}{|l|}{ Idealized Influence } \\
\hline I make others feel good working with me. & 5.27 & Somewhat Agree \\
\hline I believe that others are proud to be associated with me. & 4.94 & Somewhat Agree \\
\hline I talk about my life's important values and beliefs to my employees. & 5.09 & Somewhat Agree \\
\hline Weighted Mean & 5.10 & Somewhat Agree \\
\hline \multicolumn{3}{|l|}{ Inspirational Motivation } \\
\hline $\begin{array}{l}\text { I encourage employees to make the most of their skills and capabilities in doing } \\
\text { their jobs. }\end{array}$ & 5.52 & Agree \\
\hline I help others find meaning in their work. & 5.27 & Somewhat Agree \\
\hline I articulate a compelling vision for the future. & 5.06 & Somewhat Agree \\
\hline Weighted Mean & 5.28 & Somewhat Agree \\
\hline \multicolumn{3}{|l|}{ Intellectual Stimulation } \\
\hline I enable others to think about old problems in new ways. & 5.00 & Somewhat Agree \\
\hline I provide others with new ways of looking at things. & 5.00 & Somewhat Agree \\
\hline I get others to rethink ideas that they had never done before. & 4.82 & Somewhat Agree \\
\hline Weighted Mean & 4.94 & Somewhat Agree \\
\hline \multicolumn{3}{|l|}{ Individualized Consideration } \\
\hline I let others know I am aware of the job well done. & 5.06 & Somewhat Agree \\
\hline I give personal attention to others who seem confused in work. & 4.85 & Somewhat Agree \\
\hline I give careful attention to the working conditions of my employees. & 5.24 & Somewhat Agree \\
\hline Weighted Mean & 5.09 & Somewhat Agree \\
\hline \multicolumn{3}{|l|}{ Risk Acceptance } \\
\hline I think making risky decisions alone does not bother me at all. & 3.97 & Neither Agree nor Disagree \\
\hline I think intuition can be one of the best guides in making decisions. & 4.30 & Neither Agree nor Disagree \\
\hline I make quick decisions whenever necessary. & 5.06 & Somewhat Agree \\
\hline Weighted Mean & 4.44 & Neither Agree nor Disagree \\
\hline Overall Weighted Mean & 4.97 & Somewhat Agree \\
\hline
\end{tabular}

On the other hand, the average weighted mean obtained in Risk Acceptance was an indication that they were a little wary of taking the risk and would tend not to make a decision alone, nor to trust their intuition too much. It would likely take them sometime before coming up with a decision, which may delay operations if not moderated.

\section{Transactional Leadership of Entrepreneurs}

In terms of transformational leadership, the study revealed that the respondents were highest in Contingent
Reward (WM $=5.20)$ and lowest in Laissez-Faire Leadership ( $\mathrm{WM}=4.85)$. This means that the respondents tend to tell others what to do if they want to be rewarded for their work, and sincerely reward them if they reach their goal/s. Likewise, they tend to care what their employees do particularly when the work is absolutely essential and are not contented with letting others act on their own. 
Table 3. Transactional Leadership Ratings of Entrepreneurs

\begin{tabular}{|c|c|c|}
\hline Transactional & $\begin{array}{c}\text { Weighted } \\
\text { Mean }\end{array}$ & Verbal Description \\
\hline \multicolumn{3}{|l|}{ Contingent Reward } \\
\hline I tell others what to do if they want to be rewarded for their work. & 4.94 & Somewhat Agree \\
\hline I provide recognition or reward them when they reach their goals. & 5.36 & Agree \\
\hline $\begin{array}{l}\text { I expect employees to meet and adhere to company policy and recognize them for } \\
\text { their achievement. }\end{array}$ & 5.30 & Somewhat Agree \\
\hline \multicolumn{3}{|l|}{ I provide recognition/rewards when others reach their goals. } \\
\hline Weighted Mean & 5.20 & Somewhat Agree \\
\hline \multicolumn{3}{|l|}{ Management-By-Exception } \\
\hline I am satisfied when others meet the agreed-upon standards. & 5.48 & Agree \\
\hline As long as things are working well, I do not try to change anything. & 4.70 & Somewhat Agree \\
\hline I tell others the standards they have to know in carrying out their work. & 5.24 & Agree \\
\hline Weighted Mean & 5.18 & Somewhat Agree \\
\hline \multicolumn{3}{|l|}{ Laissez-Faire Leadership } \\
\hline I am contented to let others act on their own. & 4.42 & Somewhat Agree \\
\hline Whatever others want to do is fine with me. & 3.06 & Somewhat Disagree \\
\hline I don't care much what others do unless the work is absolutely essential. & 4.45 & Neither Agree nor Disagree \\
\hline Weighted Mean & 4.85 & Somewhat Agree \\
\hline Overall Weighted Mean & 4.77 & Somewhat Agree \\
\hline
\end{tabular}

The result of the study implies that the entrepreneurs involved in the study tend not to relax in their supervision of their employees. In fact, they would make sure that their employees know that their accomplishments are important and that they are willing to reward the anticipated accomplishments. Evidently, they are not the trusting types.

Relationship between the Profile of the Entrepreneurs and their Leadership Styles

Table 4. Computed r-value and p-value

\begin{tabular}{|l|c|c|c|c|}
\hline \multicolumn{1}{|c|}{ Profile } & \multicolumn{2}{c|}{ Transactional } & \multicolumn{2}{c|}{ Transformational } \\
\hline & (r-value) & p-value & (r-value) & p-value \\
\hline Age & -.186 & .308 & $-.432^{*}$ & 0.014 \\
\hline Sex & .265 & .136 & 0.186 & 0.3 \\
\hline Civil Status & -.037 & .839 & -0.131 & 0.467 \\
\hline Highest Educational Attainment & -.215 & .229 & -0.135 & 0.453 \\
\hline \multicolumn{1}{|c|}{ Length of Service } & -.022 & .905 & -0.078 & 0.666 \\
\hline
\end{tabular}

*correlation is significant@0.05 level 
Statistics show that the profile variables did not significantly relate to any construct of either transactional and transformational leadership styles, except for age that negatively but significantly correlated with transformational leadership with a computed $r$-value of -.43 . This means that the higher the age of the respondent, the lower his/her transformational leadership tendencies get. This implies that young entrepreneurs tend to be more transformational than their older counterparts.

\section{CONCLUSIONS AND RECOMMENDATIONS}

This study purported to determine the transactional and transformational leadership styles of the entrepreneurs involved in the Kapatid Mentor Me Program consisted of Batches 1 and 2 of the Department of Trade and Industry in Cabanatuan City and relate the entrepreneurs' tendencies correlated to age, sex, civil status, educational attainment and length of experience as entrepreneur/s.

Using descriptive research design with 33 entrepreneurs involved in the program as respondents, and using as data gathering instrument a validated questionnaire adapted from previous research, the study was conducted with the assumption that leadership styles in some ways define success in any business undertaking.

The study found out that the majority of the respondents were of age ranging from 40 to 49 , female (20 or $60.6 \%)$; married (28 or $84 \%$ ); college graduates ((22 or $66.7 \%$ ); and into entrepreneurship for about five (5) to nine (9) years (13 OR 39.4\%) already. They were more transformational than transactional leaders as indicated by their higher overall mean in the said leadership style (WM = 4.97) than in the other ( $\mathrm{WM}=4.77)$.

It was further found out that among the profile variables, only age was found to be significantly but negatively correlated with transactional leadership styles (Ramos, et al., 2019).

Based on the findings, the study recommends the following: 1) that the Kapatid Mentor Me Program be continuously improved and implemented such that participants would be more aware and understand the different leadership styles that may be used to guide them in the management of their business; 2) that the respondents be mentored in terms of Risk Acceptance and Laissez-Faire approaches. Lastly, further study must be conducted to determine the other significant correlates of business success, such as organizational culture (Subia, Mones \& Alfonso, 2017) \& corporate social responsibilities (Mina, et al, 2019) to improve work motivation and job satisfaction of employees (Bautista \& Balaria, 2018).

\section{REFERENCES}

[1] Aarons, G. (2007) Transformational and Transactional Leadership: Association With Attitudes Toward EvidenceBased Practice, Psychiatr Serv. https://www.ncbi.nlm.nih.gov/pmc/articles/PMC1876730/

[2] Asiimwe, J. et al. (2013) The Relationship between Transactional Leadership Style and SMEs Growth in the Top 100 SMEs in Kenya. International Journal of Business and Social Science, Vol. 7, No. 7, July 2013 https://ijbssnet.com/journals/Vol_7_No_7_July_2016/8.pdf

[3] Bass, Bernard M., and Ruth Bass. The Bass Handbook of Leadership: Theory, Research, and Managerial Applications. New York: Free, 2008. Print, 89.

[4] Bass, B.M., Avolio, B.J. and Atwater, L. (1996).The Transformational and Transactional Leadership of Men and Women. Applied Psychology: An International Review, Volume 45, 5 - 34

[5] Bautista, A., and Balaria.F.(2018). "Work Motivation and Job Satisfaction of Employees before and after Company Reorganization: A Case of an Electric Cooperative in the Philippines." International Journal of Advanced Engineering, Management and Science, vol. 4, no. 12.

[6] Ben, E. and Agu, A. (2018) Impact of Transformational and Transactional Leadership on Organizational Performance. International Journal of Current Research, Vol. 4. https://www.researchgate.net/publication/324978263

[7] Hoxha, A. (2019) Transformational and Transactional Leadership Styles on Employee Performance. International Journal of Humanities and Social Science Invention (IJHSSI) 
ISSN (Online): 2319 - 7722, ISSN (Print): 2319 - 7714 , Volume 8 Issue 11 Ser. III, PP 46-58

[8] Hurduzeu, R. (2015) The Impact of Leadership on Organizational Performance, SEA- Practical Application of Science, Vol.III, Issue (7)/ 2017 https://seaopenresearch.eu/Journals/articles/SPAS_7_40.pdf

[9] Khan, A. and Adnan, N. (2014) Impact of Leadership Styles on Organizational Performance. International Journal of Management Sciences, Research Academy of Social Sciences, $\quad$ Vol $2 \quad$ (11), $\quad$ pp. $\quad 501-515$ https://ideas.repec.org/a/rss/jnljms/v2i11p2.html

[10] Lai, Fong-Yi. Et al. (2020) Transformational Leadership and Job Performance: The Mediating Role of Work Engagement. SAGE Journals https://journals.sagepub.com/doi/10.1177/2158244019899085

[11] Leonard, K. (2019) The Impact of Organizational Performance. Small Business/ Human Resource/ Organizational Leadership. Updated Feb. 5, 2019. https://smallbusiness.chron.com/impact-leadershiporganizational-performance-2970.html

[12] Mahdinezhad, M. et al. (2013) Transformational, Transactional Leadership Styles and Job Performance of Academic Leaders, International Education Studies; Vol. 6, No. 11; 2013 ISSN 1913-9020 E-ISSN 1913-9039, Published by Canadian Center of Science and Education

[13] Raza, T. (2011) Exploring Transformational and Transactional Leadership Styles, IRC, Queens University, Publication Date: November 2011 https://irc.queensu.ca/articles/exploring-transformational-andtransactional-leadership-styles

[14] Ramos,J., Salangsang,S., Nacpil,L., Subia, G. and Cruz, J.(2019). Leadership Styles of Industrial Engineers in Pottery Industries in Pampanga. International Journal of Advanced Engineering, Management and Science (IJAEMS) [Vol-5, Issue-6, Jun 2019] https://dx.doi.org/10.22161/ijaems.5.6.10 ISSN: 2454-1311

[15] Subia,G.,Mones, E.and Alfonso, A.(2018). Existing and Preferred Organizational Culture at Wesleyan University Philippines. International Journal of Management and Commerce Innovations. ISSN 2348- 7585, Vol.5, Issue 2, pp: (796-801)
[16] Xiaoxia, P. et al. (2006) Transformational Leadership VS. Transactional Leadership: The Influence of Gender and Culture on Leadership Styles of SMEs in China and Sweden. Kristianstad University, The Department of Business Studies, FEC 685, Master Dissertation https://www.divaportal.org/smash/get/diva2:230525/FULLTEXT01.pdf 